\title{
Investigating the Dynamic Link between External Reserves and Monetary Variables
} in Nigeria

\author{
Nzeh, Innocent Chile \\ Ahamba, Kenneth Onyeanuna ${ }^{2}$ (D) \\ Millicent Adanne Eze ${ }^{3}$ (D) \\ Akaolisa, Chidiogo Jane ${ }^{4}$ (D) \\ Nkamnebe, Ogochukwu Edith ${ }^{5}$
}

Department of Economics, Renaissance University Ugbawka, Enugu State, Nigeria.

'Email:nzechile@yahoo.com Tel: +234-8034222084

Department of Economics and Development Studies, Federal University Ndufu-Alike, Ebonyi State, Nigeria.

Email:kendrys4jesus@yahoo.com Tel: +234-7035767251

${ }^{3}$ School of Business, Law and Social Sciences, Abertay University, Dundee, United Kingdom.

${ }^{3}$ Email:ezemillicent@gmail.com Tel: (+44)745945210s

${ }^{4,5}$ Department of Economics, Nnamdi Azikiwe University, Awka, Anambra State, Nigeria.

${ }^{4}$ Email:cjakaolisa@unizik.edu.ng.Tel: +234-8036044103

${ }^{5}$ Email:oe_nkamnebe@unizik.edu.ng.Tel: +234-8022447451

\begin{abstract}
Nigeria is a country whose revenue base is woven around the oil sector. Consequently, any shock to the international price of oil definitely affects the reserve position of the country. Our major motivation for this study is therefore anchored on the volatile nature of the country's reserves and how domestic monetary variables respond to shocks in the external reserves as well as possible reverse responses of external reserves to changes in monetary variables. Using monthly series over a period of 2007-2019 and under the framework of the VAR, our findings revealed a dynamic relationship that exists between external reserves and monetary variables in Nigeria. That is, as monetary variables responded to shocks in external reserves, a reverse response was also noticed running from external reserves to changes in monetary variables. The impact of oil to the economy was exhibited in the result as external reserves responded positively to oil price shocks; thus showing the importance of the oil sector to the country's reserve position. We therefore recommend that a synergy should exist between monetary and fiscal authorities in order to neutralize the destabilizing effect of unsustainable increase in reserve inflows and to diversify the economy away from the oil sector to reduce volatility in reserves inflows.
\end{abstract}

Citation | Nzeh, Innocent Chile; Ahamba, Kenneth Onyeanuna; Millicent Adanne Eze; Akaolisa, Chidiogo Jane; Nkamnebe, Ogochukwu Edith (2021). Investigating the Dynamic Link between External Reserves and Monetary Variables in Nigeria. Growth, 8(1): $1-11$.

History:

Received: 21 May 2021

Revised: 18 June 202

Accepted: 9 July 2021

Published: 26 July 2021

Licensed: This work is licensed under a Creative Commons

Attribution 3.0 License (cc) $\mathrm{Er}$

Publisher: Asian Online Journal Publishing Group
Acknowledgement: All authors contributed to the conception and design of the study.

Funding: This study received no specific financial support.

Competing Interests: The authors declare that they have no conflict of interests.

Transparency: The authors confirm that the manuscript is an honest, accurate, and transparent account of the study was reported; that no vital features of the study have been omitted; and that any discrepancies from the study as planned have been explained.

Ethical: This study follows all ethical practices during writing.

\section{Contents}

1. Background to the Study.

2. Literature Review

3. Methodology

4. Interpretation of Results and Discussion of Findings

5. Conclusion and Policy Recommendations

References. 


\section{Contribution of this paper to the literature}

In this research paper, we contribute to literature by investigating the responses and reverse responses between external reserves and monetary variables in Nigeria. We are motivated by the fact that the link between external reserves and monetary variables is by no means a oneway relationship.

\section{Background to the Study}

Accumulation of external reserves has become essential for countries irrespective of the type of exchange regime they operate. As observed by Carlos, Pierre, Joachim, Francis, and Simone (2004) the traditional objectives of external reserves holding is the monetary policy and exchange rate management whether under fixed or managed exchange rate regimes. Under a fixed exchange rate system, the monetary authorities may encounter a situation in which they must use reserves to maintain the fixed exchange rate. In a floating rate regime, reserves are also needed to maintain the targeted exchange rate within the bands prescribed by the monetary authorities. According to Shijaku (2012), all liquid assets held in foreign currency by the central bank constitute a country's foreign reserves. The report from the IMF (2009) also noted that foreign reserves are assets of central banks held in different reserves currencies such as the dollar, pound sterling, euro, yen etc. Foreign reserves position of a country improves when foreign exchange receipts exceed foreign exchange disbursements.

The importance of keeping external reserves has been identified as paramount for sound macroeconomic operation. Adequate external reserves lubricates international trade in terms of exchange rate and other related external obligations. In periods of financial shock, holding of external reserves become essential as it improves a country's credit rating (Umeora, 2013). In their observation, Archer and Halliday (1998) noted that the Central Bank of Nigeria (CBN) maintains external reserves to ensure exchange rate stability, creditworthiness, tackling emergency fund and as a buffer to cushion the effect of unexpected capital outflows. Thus, holding of external reserves has come to be a major preoccupation of monetary authorities, especially in resource rich developing countries that experience volatility in the export of their commodities.

The Nigerian economy is propelled by revenue from the oil sector which contributes a larger part of the country's reserves apart from other sources such as foreign direct investment, portfolio investment, remittances, among others. Consequently, any shock to the oil sector which affects the reserves position of the country will have repercussions on the country's macroeconomic environment. The management of external reserves in Nigeria is the responsibility of the $\mathrm{CBN}$ as enshrined in the CBN Act of 2007. The monetary authorities are always jolted each time there is a shock to the country's external reserves. This is because of the dynamic relationship between external reserves and other monetary variables. For instance, foreign exchange can be affected by fluctuations in the external reserves and this happens when the monetary authorities adjust the volatility in their domestic currency through the selling or buying of foreign exchange. The depreciating value of the domestic currency that makes it a less attractive investment option can be seen as a consequence of low level of reserves because the reserves level is not adequate to ensure the stability of the domestic currency. Irefin and Yaaba (2011) opined that in periods of exchange rate fluctuations, the monetary authority of a country may use their external reserves stock to stabilize the exchange market with the aim of dampening the exchange rate volatility.

In another vein, the link between external reserves and interest rate has been observed by some researchers. As noted by Bird and Rajan (2003); as a short term monetary policy tool, interest rate is used by the monetary authorities to influence the level of foreign reserves of a nation. As a country's interest rate rises, the value of the domestic currency rises. This is because a high domestic interest rate in relation to external interest rate will spur foreign investment and as this becomes sustainable, domestic currency appreciates. Nigeria is a typical country with already a high domestic interest rate and we believe that any factor that raises it further such will have implications for capital inflows and hence, reserves accretion. Owing to the high domestic interest rate in Nigeria, the monetary authorities, despite the pressures on them to use monetary policy tools to rein in inflation, are reluctant to do so even though the maintenance of price stability is the main policy objective of the CBN. Some researchers have argued that the accumulation of external reserves requires a moderate inflation. However, high inflation seriously impacts on a country's reserves accumulation through its effect on investments and productivity growth. Therefore, the monetary authorities in Nigeria face a dilemma in the sense that if they choose to reduce domestic interest rate to fight inflation, they attract lesser reserves and if they want to allow a high interest rate to attract capital inflows, inflation rises.

Perhaps, the link between external reserves and money supply is more pronounced and direct as it affects other monetary variables. Tule (2015) contended that external reserves provide monetary authorities means of influencing the supply of money in an economy as well as maintaining equilibrium in the foreign exchange market by way of policy intervention. As the CBN sells foreign exchange to the commercial banks, this results into a drop in the level of external reserves which in turn, reduces domestic supply of money. In another direction, the buying of foreign exchange by the CBN from the commercial banks leads to increased reserves level and thus, increasing the level of domestic money supply. With the foregoing background, it is pertinent to note that as monetary variables respond to external reserves, external reserves also responds to monetary variables and these possibilities form the major objective of this study. Therefore, we broaden the horizon of this topic by looking beyond the responses of external reserves to changes in monetary variables but we also considered the possibility of reverse responses running from monetary variables to shocks in external reserves.

\subsection{Some Stylized Facts}

Over the years, there have been fluctuations in the trend of some key monetary variables in Nigeria. Figure 1 below displays the trend in exchange rate in Nigeria. Evidence from the figure shows that exchange rate has been fluctuating over the years, though in an upward trend. It has been experiencing a lower trend up to 2014 when it assumes a rising trend. During 2014, so many factors led to the gradual deprecation of the exchange rate. These factors include the impact of the US Fed's interest rate policy, failing oil prices and foreign exchange reserves depletion. Notwithstanding the exchange rate depreciation within this period, the rate was never above 97 naira to 
a dollar and this feat was achieved due to the favorable monetary policy put in place by the then regime which gave confidence to foreign investors. It was during this regime also that the country was rated as the biggest economy in Africa owing to the rebasing of the economy. However, as the leadership changed baton in 2015, the country's domestic currency began to experience depreciation. Certain exchange rate policy measures put in place affected Diaspora remittances and hence, the level of foreign currency inflows into the country. Also, the intensification of banditry, mostly in the Northern part of the country and the inconsistent policies of the administration dampened investors' confidence and this is not helped by falling oil prices. The last straw that broke the Carmel's back was the macroeconomic impact of the COVD-19 pandemic, especially its effect on crude oil demand internationally. In addition to all these, the country has been devaluing the domestic currency in recent times.

\section{EXCHR}

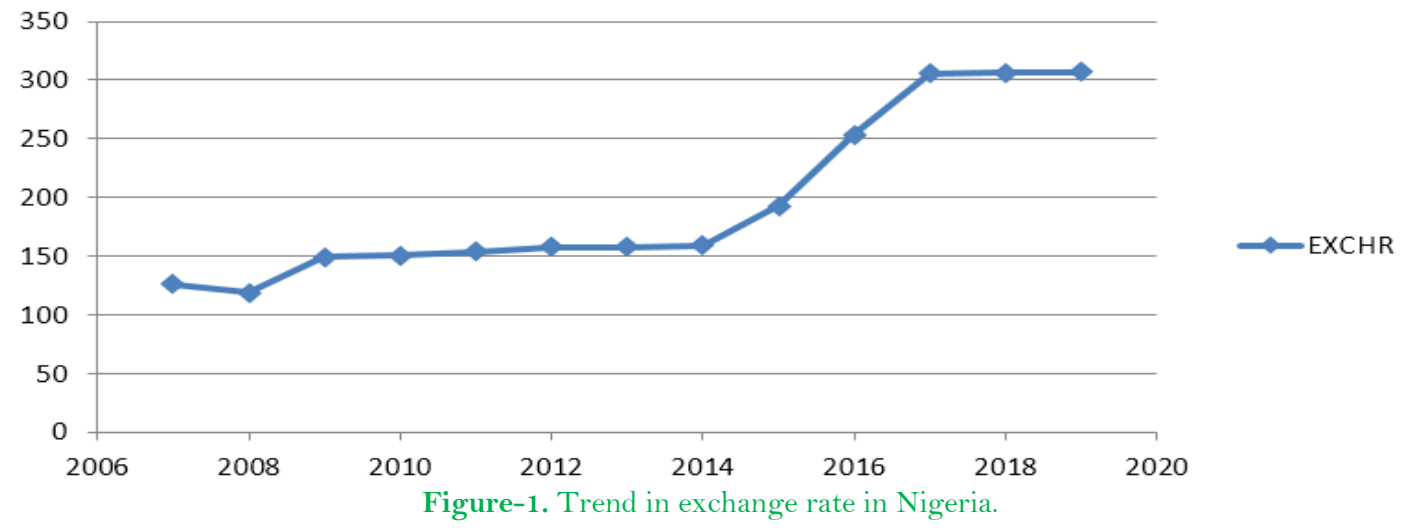

There has been a rising trend in inflation rate over the years as depicted in Figure 2 below. Since 2006, inflation has been rising until it got to a peak around 2009. Starting from 2015, it began to experience a new wave of rising trend. The intensification of the herdsmen activities in several parts of the farming communities in the country within this period led to disruption of farming activities. Many a times, farmers abandon their farms out of fear of being kidnapped or even killed by the herdsmen who roam about looking for pastures for their cattle. The aftermath of this is rising food inflation which was given additional fillip by the ban on some essential commodities by the government such as rice. More so, the rising cost of production is another factor that has been fuelling inflation in the country.

INFLR

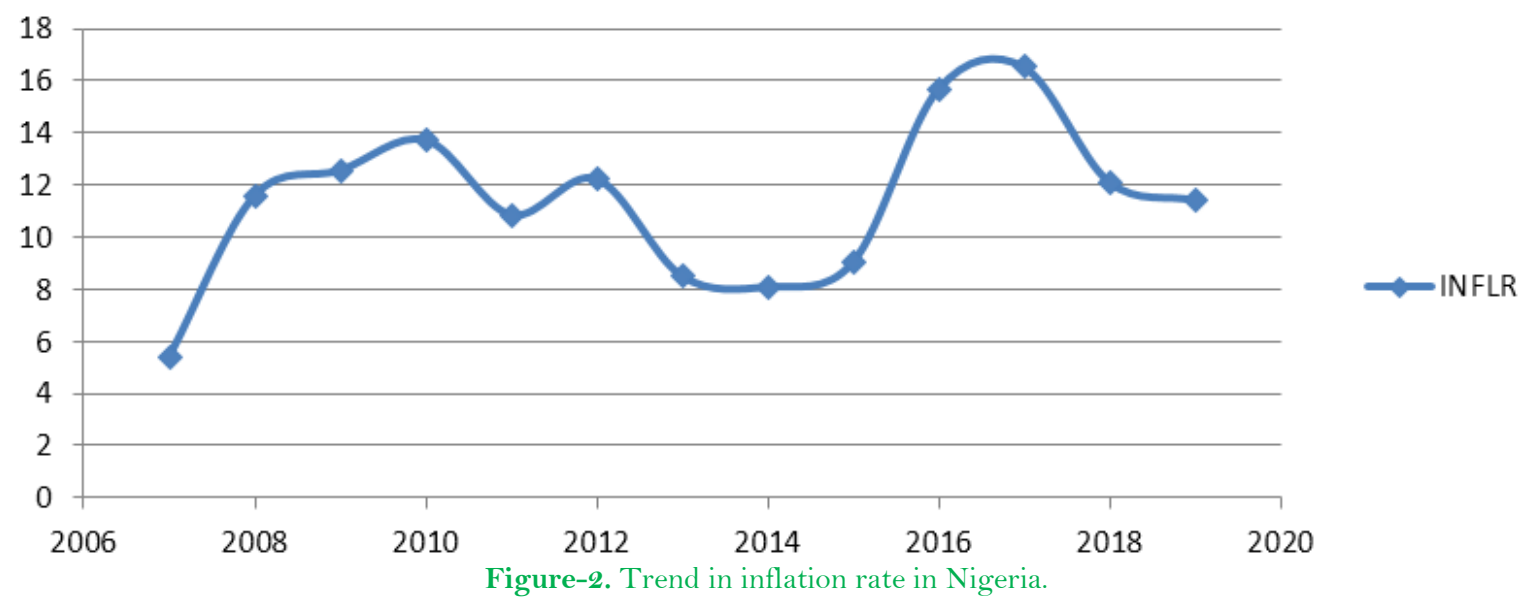

Fluctuations in interest rate are also a phenomenon in Nigeria. In Figure 3 below, the interest rate assumed a very high trend around 2009. Around this period there was a recession in the country that was transmitted from the economic turmoil in the United States of America. Most of the banks in the country within this period suffered systemic illiquidity and as such interest rate rose high. However, reforms put in the banking sector through recapitalization led to improvements in the performance of the banks that resulted in lower interest rate soon after the crisis. Soon after 2010, the major policy thrust of the CBN was to moderate price stability. According to the CBN, the monetary policy stance of the Bank within the period under review is how to contend with the growth in liquidity arising from the 2009-2010 monetary easing. Another worry was the anticipated inflationary impact of the expansionary fiscal stance of the moment as well as the gloomy global economic outlook. With respect to these developments, the Bank embarked on a tightening policy which gave rise to an increase in the monetary policy rate (MPR) from $6 \%$ to $12 \%$ which raised interest rate after it declined around 2010. In 2018, another tightening measure was put in place owing to the sluggish recovery in output, rising inflation rate and liquidity build up in the banking system and this resulted in rising interest rate. 


\section{INTR}

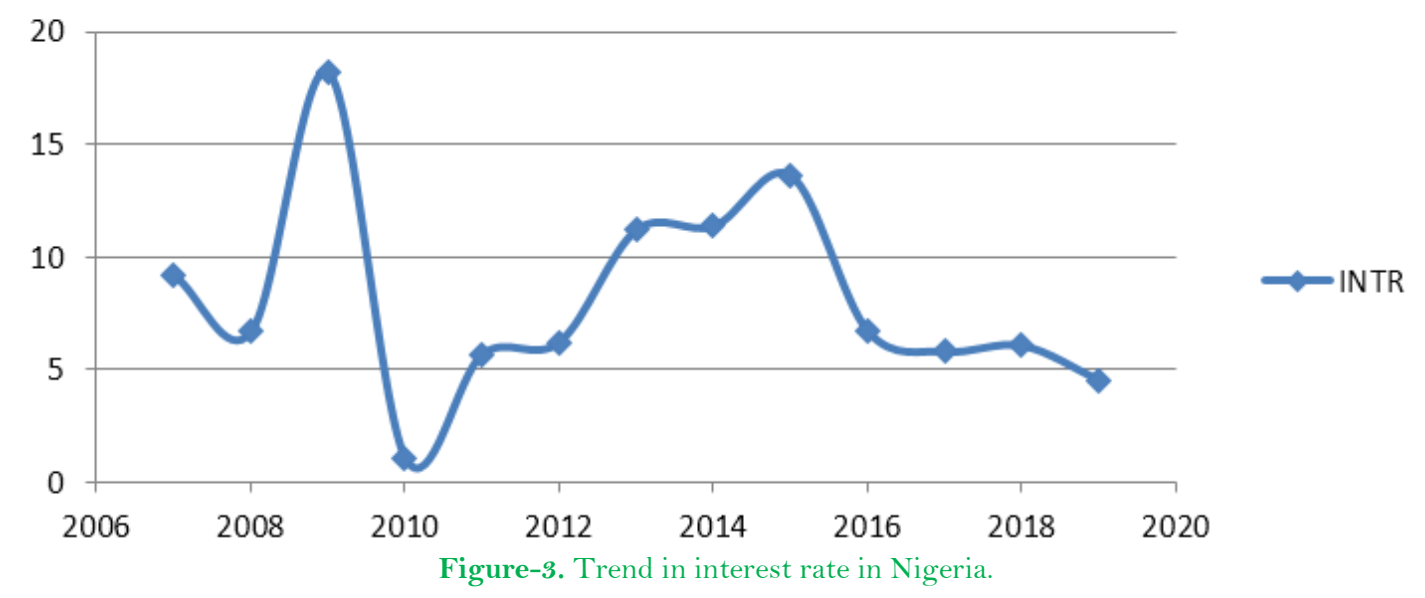

The fluctuating trend in reserves as evidenced in Figure 4 shows that the reserve position of the country has always been experiencing fluctuations. This volatile nature of the country's reserves is influenced mainly by the volatility in oil price. Around 2008, the improvement in reserves was as a result of sustained recovery in oil and other commodity prices and improved oil production. The failing oil price of 2014 led to the depletion of the foreign reserves which continued to decline until around 2016 when it experienced an increasing trend. Currently, as a way to boost external reserves, the CBN introduced a scheme that promises to reward remittances beneficiaries five naira to every one dollar sent from abroad. This rule becomes necessary as it has become glaring that Diaspora remittances generates much foreign exchange to the tune of some billions of dollars annually. Also, those in authority have been supporting the quest to incur more external debts on grounds of improving the reserves.

\section{RESERVES}

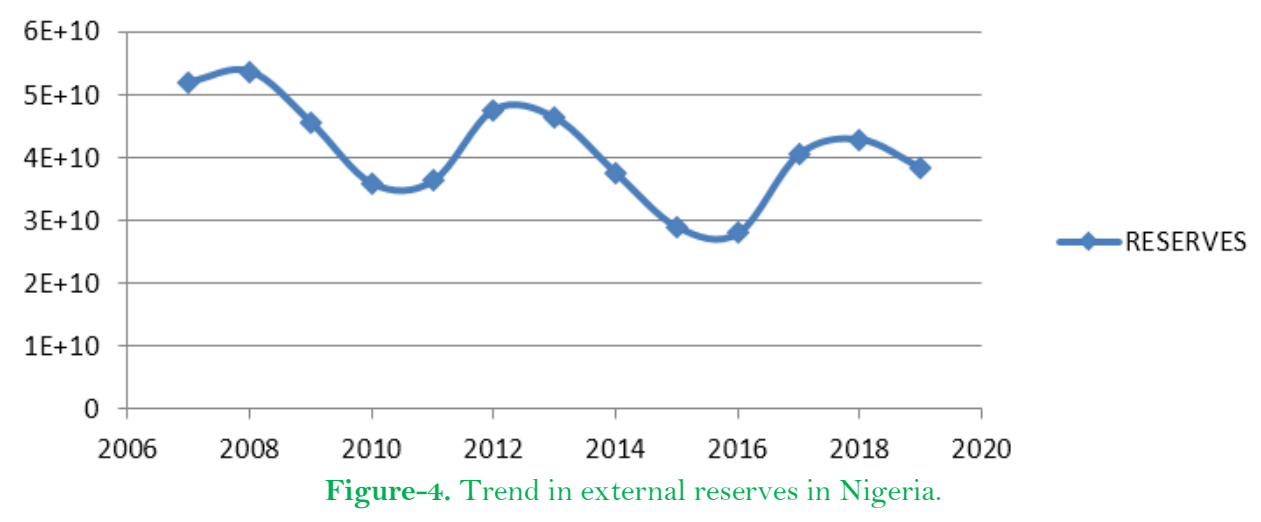

\section{Literature Review}

In this study we reviewed both the basic theory and the empirical literature at both country-specific and crosscountry level which gave the paper a direction.

\subsection{Theoretical Issues Arising from External Reserves Determinants}

The monetary theory of reserves management looks at how the monetary authorities react to fluctuations in a country's reserves. The starting point of the theory is rising domestic money supply and its domino effect on the macroeconomic aggregates. The impact of rising money supply on the macroeconomic environment is a consequence of capital inflows into the economy and this gives rise to rising external reserves. It is the assumption of the theory that foreign exchange inflows and outflows which are as a result of surpluses and deficits in a country's balance of payments are not sterilized instantly by the monetary authorities. In a fixed exchange rate regime, the need to maintain external reserves to defend the domestic currency is emphasized. Thus, the control of external reserves can be carried out through monetary policy which can be used to influence credit. There is also the general view that in a floating rate regime, reserves are also needed to maintain the targeted exchange rate within the bands prescribed by the monetary authorities.

In literature, a common factor which has been fingered as a determinant of external reserves is the adequacy ratio of foreign reserves to imports or what is commonly term an import adequacy. Import adequacy ensures that a country can defend her current imports within some stipulated number of months even when her inflows stop. By the IMF (2000) guideline, reserves holding that can guarantee three months of imports can be regarded as adequate. A major shortcoming has been pointed out using this criterion. As noted by Irefin and Yaaba (2011) part of the reasons why some scholars become sceptical of this measure is the Asian crisis of the late 1990s which has led some experts to suggest a period of 12 months of imports. In another vein, there are still those who frown at relying only on external current account as the basis of analysis. The contention of this group is that capital account should be given attention in measuring reserves adequacy. Consequently, they argue that a country should maintain reserves that can accommodate short term debts that fall due within the succeeding year. Greenspan (1999) noted that this is otherwise known as Calvo, Guidotti and Greenspan's rule, that is, reserves equal to short term external debt. 
Another reserves measure being considered is reserves equal to $5-20 \%$ of M2. This measure is perhaps more suitable for countries who face the risk of high capital flight and which are desirous of building confidence in their domestic currencies. It has also been noted that the measure is essential for countries with poor banking system.

A buffer stock model of the demand for foreign reserves was also developed by Frenkel and Jovanovic (1981) to measure the optimal level of reserves holding. This model minimizes two costs, namely: the opportunity cost of holding high level of reserves and the adjustment of the current level of reserves to the optimal level when keeping foreign reserves too low. The model can be expressed in Equation 1 below as follows:

$$
d R(t)=\mu d t+\sigma d W(t)
$$

Where: $R t=$ reserves holding at time $\mathrm{t}$.

$W t=$ standard Weiner process which exhibits zero mean and variance $\mathrm{t}$.

$\mu=$ deterministic part of the instantaneous change in reserves.

$\sigma=$ standard deviation of the Weiner increment in reserves.

The distribution of reserves holdings $\mathrm{R}(\mathrm{t})$ is characterized by the function in Equation 2 below:

$$
R(t)=R^{*}-\mu t+\sigma d W(t)
$$

where: $\mathrm{R}^{*}$ is the optimal stock of reserves. This is obtained by the minimization of two aspects of costs namely: the adjustment cost and the earnings foregone on reserve holdings. By minimizing these two costs, the optimal stock of reserves is arrived at. This can thus be expressed in Equation 3 as follows:

$$
R^{*}=\sqrt{[2 c \sigma 2 /(2 r \sigma 2) 0.5]}
$$

where:

$c=$ fixed cost of adjustment.

$r=$ opportunity cost of holding reserves.

$\sigma=$ standard deviation of change in reserves.

As has been observed by various researchers, the equation can be estimated with the following specification in Equation 4 below:

$$
\log R t=\beta_{0}+\beta_{t} \log \sigma t+\beta_{2} \log r_{t}+\mu_{t}
$$

Where $\mu$ is white noise

Despite efforts at throwing some light on the determinants of external reserves, some people are still of the view that reserves determinants are by no means exhaustive as other factors such as institutional variables can play a huge role.

\subsection{Empirical Literature}

On the realization of the roles played by a country's external reserves, so many research works have been devoted to its study at both country-specific and cross-country levels.

In Nigeria, the impact of change in external reserves positions on some macroeconomic variables was carried out (Abdullateef \& Waheed, 2010). Result of findings show that FDI and exchange rate are influenced by change in external reserves, however, domestic investment and inflation rates are not affected by change in external reserves. In a cross-country study comprising developing countries, Fukuda and Kon (2010) found that an increase in foreign exchange reserves leads to an increase in external debt outstanding and shortens debt maturity and by extension impacts on consumption. In another study for Nigeria, Irefin and Yaaba (2011), using the Autoregressive Distributed Lag (ARDL) approach, found evidence in support of income as the major determinant of reserves holdings in Nigeria. Also, Bankole, Olaniyan, Oyeranti, and Shuaibu (2011) examined the determinants of international reserves holding in Nigeria under the framework of ECM. Findings of the study show that current account variability and past levels of external reserves influence reserve holdings in the short run.

For Albania, Shijaku (2012) found a negative relationship between reserves holding and opportunity cost as well as a positive relationship with imports. Umeora (2013) in a study for Nigeria, observed a positive link between inflation rate and foreign reserves. Agénor, Alper, and Pereira (2015) adopting a dynamic stochastic model of a small open economy, found that a credit-based reserves requirement rule is necessary in reducing both macroeconomic and financial volatility. Osigwe, Okechukwu, and Onoja (2015) investigated the determinants of foreign reserves in Nigeria and found that both GDP and oil exports are determinants of reserves, while exchange rate and inflation negatively influence reserves in Nigeria. In another study for Nigeria, Nwachukwu et al. (2016), adopting a Threshold Vector Error Correction Model (TVECM), found a non-linear long-run relationship between external reserves and Bureau De Change exchange rate. In another study for Nigeria, Eniekezimene and Apere (2016) found a negative relationship between external reserves and real gross domestic product in the short run.

In Nigeria also, Senibi, Oduntan, Uzoma, Senibi, and Oluwaseun (2016), using the Johansen cointegration and FMOLS techniques, revealed a positive effect of public debt on external reserves in the long run. Using the Ordinary Least Squares (OLS) regression technique, Nwafor (2017) revealed that there is no positive impact of external reserves on economic growth in Nigeria. Also, it was found that external reserves has no positive significant influence on exchange rate in Nigeria. Izekor and Aigbovo (2018) observed that for Nigeria, exchange rate instability has little impact on foreign exchange reserves both in the short-run and in the long-run.

In a study for 9 emerging countries, Allegret and Allegret (2018) in a framework of TVAR, found that the effectiveness of reserves holding to improve the resilience of domestic economies to shocks has increased over time. In another cross-country study involving five far Eastern countries, Lee and Yoon (2020) observed that the monetary authorities' motivation for stabilizing their currencies is high in Korea and Japan. Also, the causal relationship between the Korean foreign exchange reserves and the exchange rate is stronger at the rapid 
fluctuations of the variables. By applying the framework of ARDL for Nigeria, Ojiako (2020) did not find a cointegration between GDP and foreign reserves in Nigeria.

\section{Methodology}

We applied the framework of the Vector Autoregressive (VAR) in this study because of its applicability in dynamic relationship as it captures the responses of the variables to shocks arising from any of them. We are being guided by the fact that the relationship between external reserves and monetary variables are by no means a oneway traffic. For instance, a sudden bout of increased reserves, perhaps owing to rising oil price could lead to intervention by the monetary authorities through buying of foreign exchange. This exercise has the tendency of increasing domestic money supply through the increase in the monetary base. In order to cushion the effect of this, the monetary authorities could sterilize the inflows through either the open market operations (OMO) or through increased cash reserve requirement from the commercial banks. The sterilization exercise in itself, especially through the OMO has the tendency to raise domestic interest rate because in order to ensure its success, the monetary authorities have to offer attractive rates that are beyond the market rate. Rising interest rate owing to this exercise will attract further inflows and hence, increase reserves and this leads to the need to sterilize further. In this way, as external reserves influence monetary variables, monetary variables in turn influence external reserves.

In this study, we followed a sequential approach in order to achieve our objectives. The first approach we followed is to test for the order of integration of the series so as to avoid the problem of spurious regression. Having ascertained the order of integration, this guided us in the choice of co-integration technique to adopt. As all the series exhibited I (1), the Johansen co-integration technique was adopted. With the series found not to be cointegrated, we estimated a standard unrestricted VAR model by evaluating the impulse response function. The impulse response function assists in estimating the response of certain variables to the shock produced by other variables analyzed in the model (Voda, Duguleana, \& Dobrota, 2019).

\subsection{Analytical Framework}

The analytical framework that guided us in this paper is based on the monetary approach to external reserves determination. The monetary approach explains changes in the balance of payments conditioned by the demand for and the supply of money. Accordingly, the approach states that the position of the balance of payments of a country is always and everywhere a monetary phenomenon and as such can be corrected using monetary mechanisms. This approach can be expressed in the form of the following link between the supply of money and the demand for money. The demand for money $\left(\mathrm{M}_{\mathrm{d}}\right)$ is a stable function of income $(\mathrm{Y})$, prices $(\mathrm{P})$ and the rate of interest (i). Equation 5 below displays this link.

$$
M_{d}=f(Y, P, i)
$$

Where $\mathrm{M}_{\mathrm{d}}=$ money demand, $\mathrm{Y}=$ income level and $\mathrm{P}=$ rice level

The supply of money $\left(\mathrm{M}_{\mathrm{s}}\right)$ is comprised of monetary base $(\mathrm{M})$ which by itself consists of domestic money (credit or D) and a country's foreign exchange reserves (R). Since $\mathrm{M}$ is a constant, we have to ignore it. Therefore, the money supply can be expressed in Equation 6 as below:

$$
M_{s}=D+R
$$

Since in equilibrium the demand for money equals the supply of money, we have the following equilibrium situation as indicated in Equation 7 below:

$$
M_{d}=M_{s} \text { or } M_{d}=D+R
$$

A balance of payments deficit or surplus is represented by changes in a country's foreign reserves. This is expressed in Equation 8 below:

$$
\Delta R=\Delta M_{d}-\Delta D
$$

Where $\Delta \mathrm{R}=$ change in externa reserves, $\Delta \mathrm{M}_{\mathrm{d}}=$ change in money demand and $\Delta \mathrm{D}=$ change in domestic credit

\subsection{Model Specification}

Our model specification is a modification of the monetary approach to external reserves from the work of Bankole et al. (2011). Nigeria, being an oil dependent economy whose reserves position is usually shaped by exogenous oil price, we included oil price in the model to account for the response of external reserves to volatility in oil price. The model for the monetary approach is specified in Equation 9 as follows:

$$
R=K_{0}+K_{1} P L+K_{2} R D I+K_{3} D B H+K_{4} M S S+\varepsilon
$$

Where $\mathrm{K}=$ reserves, $\mathrm{PL}=$ the price level, $\mathrm{RDI}=$ real domestic income, $\mathrm{DBH}=$ domestic bond holding and MSS = domestic money supply. The rate of inflation is used to proxy the price level, while the prime lending rate (MPR) is used to proxy domestic bond holding. We opted for the MPR because it is the benchmark rate which the monetary authorities use to influence other rates. The broad money supply (M2) is used as a proxy for money supply. We did not include real GDP in the model because of the absence of monthly data on the variable in Nigeria, however; we included oil price level since Nigeria's reserves position is mainly determined by the oil sector. We also included exchange rate in the model to account for the influence of exchange rate volatility. To capture the dynamics in the relationship among the variables, the VAR specification of the above model is shown in Equation 10 below:

where:

$$
X_{t}=C+\sum_{i=1}^{p} \mathrm{~A}_{i} X_{t-i}+\varepsilon_{t}
$$


$X_{t}=(6 x 1)$ random vector of endogenous variables which include: external reserves, exchange rate, inflation rate, money supply (M2), monetary policy rate and oil price. $\mathrm{A}_{\mathrm{i}}=$ fixed coefficient matrix, $\mathrm{C}=$ fixed intercept terms, $\varepsilon_{\mathrm{t}}=$ white noise, $\mathrm{p}=$ lag order. We can represent the above in form of an unrestricted VAR model as shown in Equations 11- 16 as follows:

$$
\begin{aligned}
& \triangle E X R E S E R V_{t}=\alpha_{1}+\sum_{j=1}^{p} \beta_{1 j} \Delta E X R E S E R V E_{t-j}+\sum_{j=1}^{p} \beta_{2 j} \Delta M 2_{t-j}+\sum_{j=1}^{p} \beta_{3 j} \Delta M P R_{t-j} \\
& +\sum_{j=1}^{p} \beta_{4 j} \Delta E X C H R_{t=j}+\sum_{j=1}^{p} \beta_{5 j} \Delta I N F L R_{t-j}+\sum_{j=1}^{p} \beta_{6 j} \Delta O I L P_{t-j}+\varepsilon_{t} \\
& \Delta M 2_{t}=\alpha_{2}+\sum_{j=1}^{p} \beta_{1 j} \Delta E X R E S E R V E_{t-j}+\sum_{j=1}^{p} \beta_{2 j} \Delta M 2_{t-j}+\sum_{j=1}^{p} \beta_{3 j} \Delta M P R_{t-j} \\
& +\sum_{j=1}^{p} \beta_{4 j} \Delta E X C H R_{t=j}+\sum_{j=1}^{p} \beta_{5 j} \Delta I N F L R_{t-j}+\sum_{j=1}^{p} \beta_{6 j} \Delta O I L P_{t-j}+\varepsilon_{t} \\
& \Delta M P R_{t}=\alpha_{3}+\sum_{j=1}^{p} \beta_{1 j} \Delta E X R E S E R V E_{t-j}+\sum_{j=1}^{p} \beta_{2 j} \Delta M 2_{t-j}+\sum_{j=1}^{p} \beta_{3 j} \Delta M P R_{t-j} \\
& +\sum_{j=1}^{p} \beta_{4 j} \Delta E X C H R_{t=j}+\sum_{j=1}^{p} \beta_{5 j} \Delta I N F L R_{t-j}+\sum_{j=1}^{p} \beta_{6 j} \Delta O I L P_{t-j}+\varepsilon_{t} \\
& \Delta \operatorname{EXCHR}_{t}=\alpha_{4}+\sum_{j=1}^{p} \beta_{1 j} \Delta E X R E S E R V E_{i-j}+\sum_{j=1}^{p} \beta_{2 j} \Delta M 2_{t-j}+\sum_{j=1}^{p} \beta_{3 j} \Delta M P R_{t-j} \\
& +\sum_{j=1}^{p} \beta_{4 j} \Delta E X C H R_{t=j}+\sum_{j=1}^{p} \beta_{5 j} \Delta I N F L R_{t-j}+\sum_{j=1}^{p} \beta_{6 j} \Delta O I L P_{t-j}+\varepsilon_{t} \\
& \Delta \text { INFLR }_{t}=\alpha_{5}+\sum_{j=1}^{p} \beta_{1 j} \Delta \text { EXRESERVE }_{t-j}+\sum_{j=1}^{p} \beta_{2 j} \Delta M 2_{t-j}+\sum_{j=1}^{p} \beta_{3 j} \Delta M P R_{t-j} \\
& +\sum_{j=1}^{p} \beta_{4 j} \Delta E X C H R_{t=j}+\sum_{j=1}^{p} \beta_{5 j} \Delta I N F L R_{t-j}+\sum_{j=1}^{p} \beta_{6 j} \Delta O I L P_{t-j}+\varepsilon_{t} \\
& \Delta \text { OILP }_{t}=\alpha_{6}+\sum_{j=1}^{p} \beta_{1 j} \Delta \text { EXRESERVE }_{t-j}+\sum_{j=1}^{p} \beta_{2 j} \Delta M 2_{t-j}+\sum_{j=1}^{p} \beta_{3 j} \Delta M P R_{t-j} \\
& +\sum_{j=1}^{p} \beta_{4 j} \Delta E X C H R_{t=j}+\sum_{j=1}^{p} \beta_{5 j} \Delta I N F L R_{t-j}+\sum_{j=1}^{p} \beta_{6 j} \Delta O I L P_{t-j}+\varepsilon_{t}
\end{aligned}
$$

Where:

EXRESERVE $=$ External Reserves, M2 = Broad money supply (a proxy for money supply), MPR = Monetary policy rate, $\mathrm{EXCHR}=$ Exchange rate, $\mathrm{INFR}=$ Inflation rate, $\mathrm{OILP}=$ oil price

We applied statistical procedure in the selection of the lag length. The minimization of the information criteria is the basis for the selection of a particular lag length. In this study, since we used monthly series, the HannanQuinn information criterion is used in lag selection. According to Rummel (2015) Hannan-Quinn information criterion is typically more appropriate for quarterly and monthly data.

\subsection{Impulse Response}

In order to enable us interpret the VAR model, we utilized the framework of impulse response function. The impulse response function is expressed in Equation 17 as follows:

$$
y_{t}=\mu+\varepsilon_{t}+\varpi_{1} \varepsilon_{t-1}+\varpi_{2} \varepsilon_{t-2}+
$$

Where

$$
\varpi_{j}^{s}=\frac{\partial y i, t+1}{\partial \eta, t}=\frac{\partial y i, t}{\partial y_{,}, t-s}, i, j=1 \ldots T
$$

Equation 18 is the response of $\mathrm{y}$ in period $\mathrm{t}+\mathrm{s}$ to shock in period s. $\varpi_{s}$ is the Impulse Response Function of $\mathrm{s}$. $\varpi_{s}$ is the kxk moving average matrices and it is determined recursively in Equation 19 as follows:

$$
\varpi_{1}=\sum_{j=1}^{p-1} \varpi_{s-j} \mathrm{~A}_{j, s} \quad=1,2 .
$$

In this study, monthly series were employed covering a period of 2007-2019. The choice of the sample period was informed by data availability of some of the variables. All the data were sourced from the Central Bank of Nigeria Statistical Bulletin. 


\section{Interpretation of Results and Discussion of Findings}

In order to avoid spurious results, it is pertinent to test for the stationarity of the series. In this study, we applied both the Augmented Dickey-Fuller test (ADF) and the Phillips-Perron test (PP) and the evaluation were based on a $5 \%$ level of significance. Information in Table 1 below shows that at levels, the series are not stationary. However, as shown in Table 2, after a first difference, the series become stationary, that is, they become I (1).

Table-1. Result of Stationarity at level

\begin{tabular}{c|c|c|c|c|c}
\hline Variables & ADF t-stat. & PP t-stat. & $\begin{array}{c}\text { Critical value at } \\
\mathbf{5 \%} \text { ADF }\end{array}$ & $\begin{array}{c}\text { Critical value } \\
\text { at 5\% PP }\end{array}$ & Order of integration \\
\hline EXRESERV & -2.880336 & -2.880088 & 0.2649 & 0.3640 & Non stationary \\
\hline M2 & -2.880088 & -2.880088 & 0.9325 & 0.9474 &, \\
\hline MPR & -2.880088 & -2.880088 & 0.7727 & 0.7013 &, \\
\hline EXCHR & -2.880211 & -2.880088 & 0.8353 & 0.8411 &, \\
\hline INFR & -2.880336 & -2.880088 & 0.0826 & 0.2278 &, \\
\hline OILP & -2.880211 & -2.880088 & 0.1605 & 0.2023 &, \\
\hline
\end{tabular}

Note: Figures with asterisks $\left.{ }^{*}\right)$ indicate the rejection of the null hypothesis at the $5 \%$ level.

\begin{tabular}{c|c|c|c|c|c}
\multicolumn{7}{c}{ Table-2. Result of Stationarity at first Difference. } \\
\hline Variables & ADF t-stat. & PP t-stat. & $\begin{array}{c}\text { Critical value } \\
\text { at 5\% ADF }\end{array}$ & $\begin{array}{c}\text { Critical value at 5\% } \\
\text { PP }\end{array}$ & $\begin{array}{c}\text { Order of } \\
\text { integration }\end{array}$ \\
\hline$\Delta$ EXRESERV & $-2.880336^{*}$ & $-2.880211^{*}$ & 0.0000 & 0.0000 & $\mathrm{I}(1)$ \\
\hline$\Delta \mathrm{M} 2$ & $-2.880211^{*}$ & $-2.880211^{*}$ & 0.0000 & 0.0000 & $\mathrm{I}(1)$ \\
\hline$\Delta \mathrm{MPR}$ & $-2.880211^{*}$ & $-2.880211^{*}$ & 0.0000 & 0.0000 & $\mathrm{I}(1)$ \\
\hline$\Delta \mathrm{EXCHR}$ & $-2.880211^{*}$ & $-2.880211^{*}$ & 0.0000 & 0.0000 & $\mathrm{I}(1)$ \\
\hline$\Delta \mathrm{INFR}$ & $-2.880336^{*}$ & $-2.880211^{*}$ & 0.0000 & 0.0000 & $\mathrm{I}(1)$ \\
\hline$\Delta$ OILP & $-2.880211^{*}$ & $-2.880211^{*}$ & 0.0000 & 0.0000 & $\mathrm{I}(1)$ \\
\hline
\end{tabular}

Note: Figures with asterisks $(*)$ indicate the rejection of the null hypothesis at the $5 \%$ level

\subsection{Lag Selection Criteria}

We chose 8 lags in the unrestricted VAR model without imposing any restriction on the coefficients. In Table 3 below, each selection criterion displays the optimal number of lags. In order to obtain the optimal lag for our study, we employed the Hannan-Quinn information criterion. Thus, to ensure the VAR stability, lag 1 is suggested by this criterion.

\begin{tabular}{c|c|c|c|c|c|c}
\hline \multicolumn{7}{c|}{ Table-3. VAR lag order selection criteria. } \\
\hline Lag & LogL & LR & FPE & AIC & SC & HQ \\
\hline 0 & -6100.805 & NA & $2.79 \mathrm{e}+28$ & 82.52440 & 82.64591 & 82.57377 \\
\hline 1 & -4711.918 & 2646.393 & $3.20 \mathrm{e}+20$ & 64.24214 & $65.09270^{*}$ & $64.58772^{*}$ \\
\hline 2 & -4669.170 & 77.98681 & $2.93 \mathrm{e}+20^{*}$ & 64.15095 & 65.73056 & 64.79274 \\
\hline 3 & -4632.948 & $63.14384^{*}$ & $2.94 \mathrm{e}+20$ & $64.14795^{*}$ & 66.45661 & 65.08595 \\
\hline 4 & -4615.798 & 28.50683 & $3.83 \mathrm{e}+20$ & 64.40267 & 67.44039 & 65.63689 \\
\hline 5 & -4591.666 & 38.15465 & $4.58 \mathrm{e}+20$ & 64.56305 & 68.32981 & 66.09348 \\
\hline 6 & -4566.576 & 37.63437 & $5.45 \mathrm{e}+20$ & 64.71049 & 69.20630 & 66.53713 \\
\hline 7 & -4547.590 & 26.93932 & $7.13 \mathrm{e}+20$ & 64.94041 & 70.16528 & 67.06326 \\
\hline 8 & -4520.561 & 36.16098 & $8.48 \mathrm{e}+20$ & 65.06163 & 71.01555 & 67.48070 \\
\hline
\end{tabular}

Note: * indicate lag order selected by the criterion LR: Sequential modified LT test statistic 9each test at $6 \%$ level)

FPE: Final prediction error AIC: Akaike information criterion SC: Schwarzt information criterion HQ: Hannan-Quinn information criterion.

\subsection{Lag Exclusion}

As a further test for the reliability of the chosen optimal lag, we employed the lag exclusion test. The P-value of the joint model variables is a guide to the possibility of using the selected lag if its value is statistically significant. That is, if the value is less than 0.05. From the Wald test in Table 4, the joint p-value is statistically significant. Therefore, the VAR model will be estimated adopting lag 1 as indicated by the Hannan-Quinn information criterion.

\begin{tabular}{c|c|c|c|c|c|c|c}
\hline & TX_RESERV & EXCHR & M2 & MPR & INFR & OILP & Joint \\
\hline Lag 1 & 287.3200 & 217.5671 & 119.0355 & 138.1847 & 161.7238 & 263.4613 & 1170.423 \\
& {$[0.000000]$} & {$[0.000000]$} & {$[0.000000]$} & {$[0.000000]$} & {$[0.000000]$} & {$[0.000000]$} & {$[0.000000]$} \\
\hline Lag 2 & 23.81785 & 14.01500 & 10.69338 & 8.106759 & 3.866680 & 18.94883 & 81.98178 \\
& {$[0.000564]$} & {$[0.029469]$} & {$[0.098328]$} & {$[0.230386]$} & {$[0.694713]$} & {$[0.004251]$} & {$[1.92 \mathrm{e}-05]$} \\
\hline Df & 6 & 6 & 6 & 6 & 6 & 6 & 36 \\
\hline
\end{tabular}

Apart from identifying the optimal lag, we also considered the stability of the VAR model. The inverse roots of the autoregressive characteristic polynomial are displayed in Figure 5 below. The criterion for a model to be stable is that the roots of the autoregressive model equation should be located inside the circle. From Figure 5 below, it should be noted that the AR process is stationary, as can be shown that the roots of the equation are found within the unit circle. 


\section{Inverse Roots of AR Characteristic Polynomial}

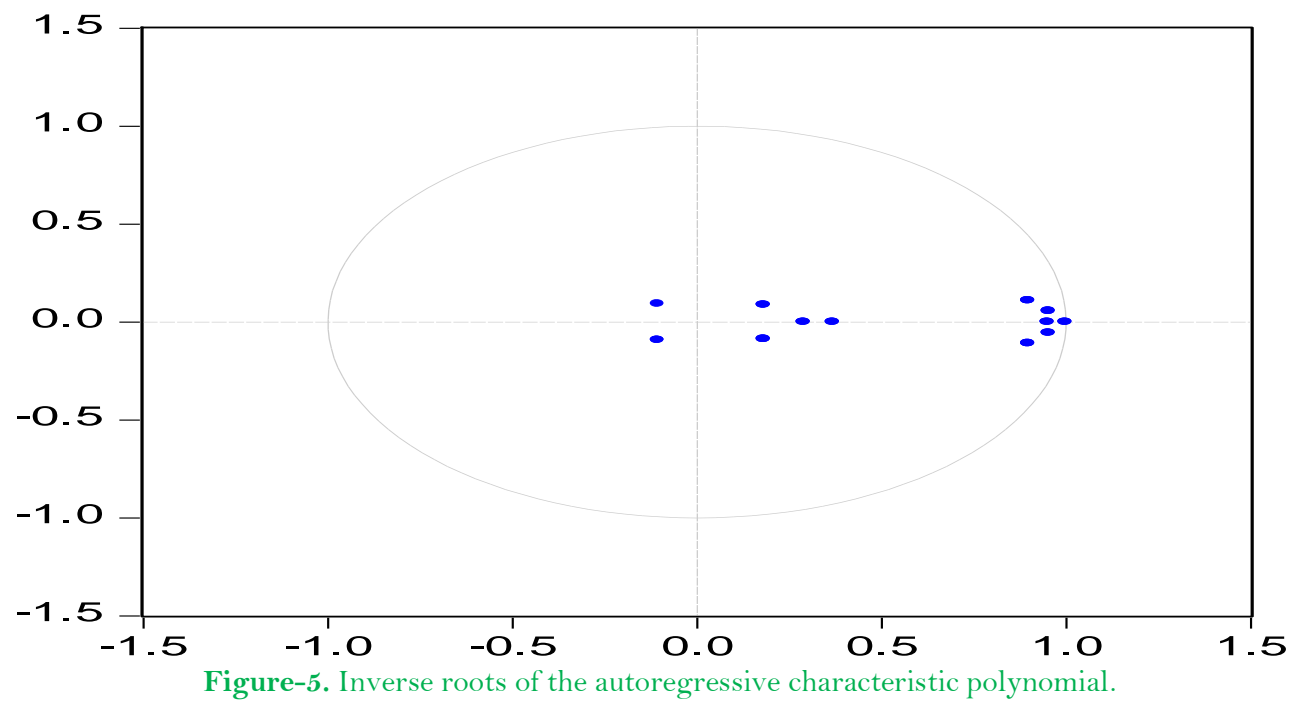

\subsection{Cointegration Results}

Since the series are integrated of order one, i.e. I (1), we adopted the Johansen cointegration test in investigating the long-run equilibrium relationship between the model variables. The Trace and Max-Eigenvalue tests guided us in achieving this. We applied the Johansen cointegration test bearing in mind the optimal lag suggested by the Hannan-Quinn information criterion. From Tables 5 and 6, with both the Trace and MaxEigenvalue tests showing a p-value that are greater than the 0.05 significance; these confirm the non-existence of a cointegration relationship. Thus, we have to consider a short-run relationship between the model variables.

Table-5. Unrestricted cointegration rank test (trace).

\begin{tabular}{l|c|c|c|c}
\hline Hypothesized No. of CE(s) & Eigenvalue & Trace Statistic & 0.05 Critical Value & Prob.*** \\
\hline None & 0.213862 & 86.84589 & 95.75366 & 0.1751 \\
\hline At most 1 & 0.123763 & 50.03059 & 69.81889 & 0.6364 \\
\hline At most 2 & 0.082763 & 29.81650 & 47.85613 & 0.7283 \\
\hline At most 3 & 0.075038 & 16.59889 & 29.79707 & 0.6695 \\
\hline At most 4 & 0.028986 & 4.664467 & 15.49471 & 0.8434 \\
\hline At most 5 & 0.001072 & 0.164039 & 3.841466 & 0.6855 \\
\hline
\end{tabular}

Note: Trace test indicates no cointegration at the 0.05 level * denotes rejection of the hypothesis at the 0.05 level.

Table-6. Unrestricted cointegration rank test (maximum eigenvalue).

\begin{tabular}{l|c|c|c|c}
\hline Hypothesized No. of CE(s) & Eigenvalue & Max-Eigen Statistic & 0.05 Critical Value & Prob.*** \\
\hline None & 0.213862 & 36.81530 & 40.07757 & 0.1114 \\
\hline At most 1 & 0.123763 & 20.21409 & 33.87687 & 0.7417 \\
\hline At most 2 & 0.082763 & 13.21760 & 27.58434 & 0.8726 \\
\hline At most 3 & 0.075038 & 11.93443 & 21.13162 & 0.5542 \\
\hline At most 4 & 0.028986 & 4.500428 & 14.26460 & 0.8031 \\
\hline At most 5 & 0.001072 & 0.164039 & 3.841466 & 0.6855 \\
\hline
\end{tabular}

Note: Max-eigenvalue test indicates no cointegration at the 0.05 level * denotes rejection of the hypothesis at the 0.05 level Table 6

Unrestricted Cointegration Rank Test (Maximum Eigenvalue).

Our unit root tests have shown that the series are integrated of order one and also the result of the cointegration test showed that the series are not cointegrated. With these results, the conditions for running the unrestricted VAR model are fulfilled. Thus, we can obtain the impulse response function.

\subsection{Interpretation of Impulse Response Results}

The impulse response function displays the evolution of the variables of interest within a specified time horizon after a shock is produced at a given time. In Appendix 1 below, external reserves responded positively to all the variables in the entire time horizon except inflation which it responded negatively in the second quarter. We also noticed that after the fourth quarter, it responded negatively to money supply. The contribution of oil to Nigeria's external reserves gave credence to the positive response of external reserves to oil price. The negative response of external reserves to inflation after some lag could be as a result of the impact of inflation on investors' confidence as it erodes capital inflows. Also, since the major monetary policy thrust of the CBN is inflation targeting, certain measures put in place to mitigate the inflationary impact of reserve inflows could lead to the negative response of external resaves to money supply. We are also of the opinion that the period of time taken for external reserves to respond negatively to money supply is because the policies put on ground to neutralize the monetary impact of reserve inflows take time to be noticeable.

Our finding also revealed that exchange rate responded positively only in the first quarter but beginning from the second quarter through the fourth quarter, it responded negatively to external reserves. We guess that the domestic currency appreciation owing to increasing reserves inflows is only felt after some period of time. Currency appreciation is one of the consequences of rising reserve inflows that make monetary authorities to use different measures to cushion the impact. Inflation responds negatively to external reserves in all the quarters. As external reserves rises, there is the tendency of money supply to rise with the rising external reserves. Inflation targeting is a major monetary policy thrust of the CBN, so in an anticipation of the inflationary impact of reserve accretion, measures are put in place to cushion the effect. Among such measures that are often adopted by the CBN 
which have an instantaneous impact is an increase in commercial banks' cash reserve ratio and a resort to Open Market Operation (OMO).

In all the quarters, the broad money supply (M2) exhibited a positive response to external reserves. This is in line with a priori expectation as a major consequence of increase reserves inflow is to cause expansion in the domestic monetary aggregates. Monetary policy rate is found to respond positively to external reserves only in the first quarter, but beginning from the second quarter all through the last quarter, it responded negatively to external reserves. By increasing money supply, domestic interest rate is expected to fall. Even though the monetary policy committee of the CBN meets monthly to influence the direction of the economy by altering key monetary policy instruments such as the MPR, the committee usually retains the existing MPR for a relatively long period of time. We also observe that oil price responded positively to external reserves in all the quarters. Indeed, since oil price is an exogenous variable, we do not expect external reserves to influence it. However, since previous result has shown that external reserves responded positively to oil price, we expect similar relationship to exist in the response of oil price to external reserves.

\section{Conclusion and Policy Recommendations}

In this study, we set out to investigate the responses of monetary variables to shocks in external reserves and vice versa. The study was informed by the volatile nature of oil price which influences the reserve position of the country and how the monetary variables respond to these fluctuations on one hand and on the other hand, how external reserves respond to the dynamics of monetary variables. Our findings so far have shown that much as monetary variables respond to external reserves, external reserves in turn responds to monetary variables and this shows the dynamic nature of the relationship. Of more sensitive in our findings are the positive response of money supply to external reserves and the currency appreciation impact of external reserves. The impact of rising external reserves inflows on these variables is a major concern of monetary authorities.

Based on the foregoing, we recommend that the monetary authorities should use effective monetary policy measures to cushion the effect of increasing and unsustainable reserves inflows. The CBN usually finds herself in a tight corner in the fight against the inflationary impact of reserves inflows and that accounts for the reasons she usually retains key monetary policy variables such as MPR and cash reserve ratio even in the face of the destabilising short term capital inflows. In the face of this situation, a synergy between monetary and fiscal policies should be maintained to curb inflation during period of high and volatile reserve inflows. On the other hand, during period of shortfall in external reserves as the country is currently undergoing, measures to boost external reserves should include a diversification of the economy away from the oil sector.

\section{References}

Abdullateef, U., \& Waheed, I. (2010). External reserve holdings in Nigeria: Implications for investment, inflation and exchange rate. Journal of Economics and International Finance, 2(9), 183-189.

Agénor, P. R., Alper, K., \& Pereira, L. (2015). External shocks, financial volatility and reserve requirements in an open economy. The Banco Central do Brasil Working Papers Series No. 396.

Allegret, J.-P., \& Allegret, A. (2018). The role of international reserves holding in buffering external shocks. Applied Economics, 50(29), 31283147. Available at: https://doi.org/10.1080/00036846.2017.1418075.

Archer, D., \& Halliday, J. (1998). The rationale for holding foreign currency reserves. Reserve Bank of New Zealand Bulletin, 61(4), 346-354.

Bankole, A. S., Olaniyan, O., Oyeranti, G., \& Shuaibu, M. (2011). Demand for international reserves: A case for reserves accumulation in Nigeria. Central Bank of Nigeria Economic and Financial Review, 49(3), 71-98.

Bird, G., \& Rajan, R. (2003). Too much of a good thing? The adequacy of international reserves in the aftermath of crises. The World Economy, 26(6), 873-891.

Carlos, B., Pierre, C., Joachim, C., Francis, D., \& Simone, M. (2004). Risk management for Central Bank foreign reserves: European Central Bank.

Eniekezimene, F. A., \& Apere, T. O. (2016). External reserve management and economic growth in Nigeria. International Journal of Empirical Finance, 5(2), 101-111.

Frenkel, J. A., \& Jovanovic, B. (1981). Optimal international reserves. Economic Journal, 91(362), 507-514.

Fukuda, S., \& Kon, Y. (2010). Macroeconomic impacts of foreign exchange reserve accumulation: Theory and international evidence. Asian Development Bank Institute (ADBI) Working Paper Series No. 197.

Greenspan, A. (1999). Currency reserves and debt. Paper presented at the Remarks before the World Bank Conference on Recent Trend in Reserve Management, Washington, DC.

IMF. (2000). Debt-and reserves-related indicators of external vulnerability. Paper presented at the Policy Development and Review Department in Consultation with other Departments, March 2000.

IMF. (2009). International monetary fund, Annual Report. Retrieved from www.imf.org/external/pubs/ft/ar/2009/eng/pdf/a 1.pdf.

Irefin, D., \& Yaaba, B. N. (2011). Determinants of foreign reserves in Nigeria: An autoregressive distributed lag approach. CBN Journal of Applied Statistics, 2(2), 63-82.

Izekor, A. O., \& Aigbovo, O. (2018). Exchange rate instability and Nigerian foreign exchange reserves: Short run and long run analyses. Amity Journal of Finance, 3(1), 50-60.

Lee, Y., \& Yoon, S.-M. (2020). Relationship between international reserves and FX Rate movements. Sustainability, 12(17), 6961. Available at: https://doi.org/10.3390/su12176961.

Nwachukwu, N. E., Ali, A. I., Abdullahi, I. S., Shettima, M. A., Zirra, S. S., Falade, B. S., \& Alenyi, M. J. (2016). Exchange rate and external reserves in Nigeria: A threshold cointegration analysis. CBN Journal of Applied Statistics, 7(1), 233-254.

Nwafor, M. C. (2017). External reserves: Panacea for economic growth in Nigeria. European Journal of Business and Management, 9(33), 36-47.

Ojiako, A. (2020). Linkages between external reserves and economic performance in Nigeria. South Asian Journal of Social Studies and Economics, 6(1), 44-62.

Osigwe, A. C., Okechukwu, A., \& Onoja, T. C. (2015). Modeling the determinants of foreign reserves in Nigeria. Developing Country Studies, $5(19), 72-77$.

Rummel, O. (2015). Economic modelling and forecasting. Centre for Central Banking Studies, Bank of England, 1-5.

Senibi, V., Oduntan, E., Uzoma, O., Senibi, E., \& Oluwaseun, A. (2016). Public debt and external reserve: The Nigerian experience (19812013). Economics Research International, 2016. Available at: http://dx.doi.org/10.1155/2016/1957017.

Shijaku, G. (2012). Optimal level of reserve holding: An empirical investigation in the case of Albania. MPRA Paper No. 79091.

Tule, M. (2015). CBN and assessment of oil prices on reserves, foreign exchange management. Central Bank of Nigeria Working Paper Series 01/2015/06.

Umeora, E. C. (2013). Accumulation of external reserves and effects on exchange rates and inflation in Nigeria. International Business and Management, 6(2), 105-114.

Voda, A. D., Duguleana, L., \& Dobrota, G. (2019). Investments, economic growth and employment: VAR method from Romania. Studies in Business and Economics, 14(2), 231-244. 
Accumulated Response of EX_RESERV to Cholesky One S.D. Innovations

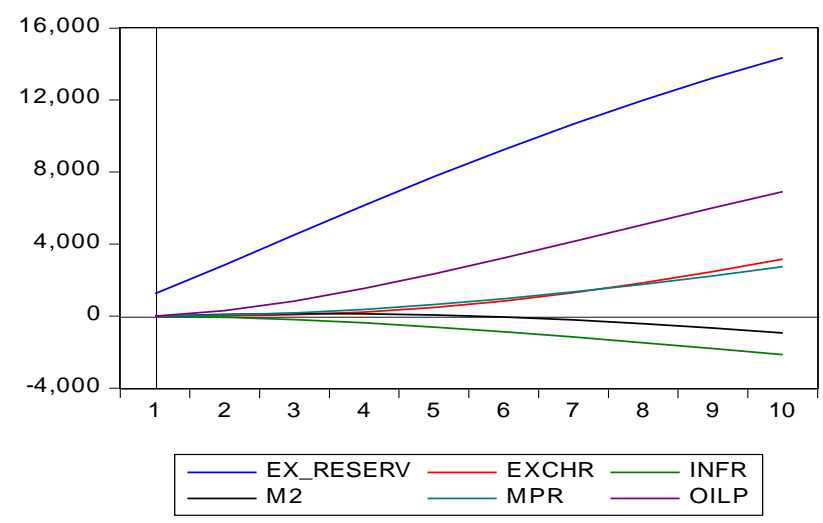

Accumulated Response of INFR to Cholesky One S.D. Innovations
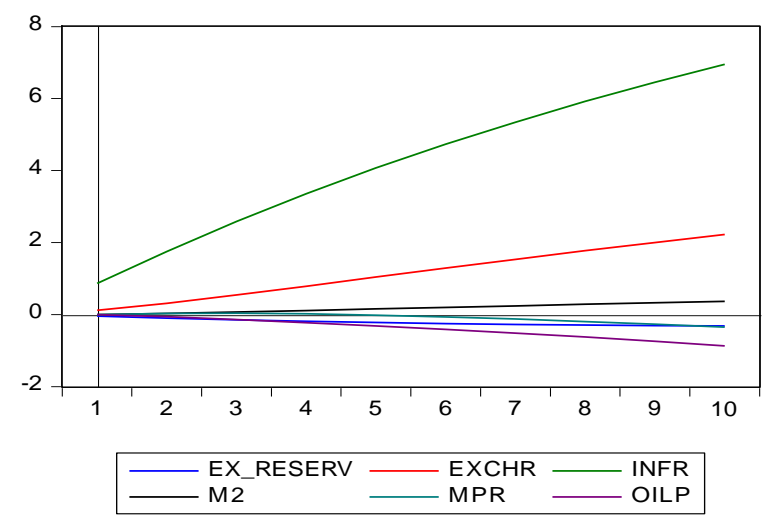

Accumulated Response of MPR to Cholesky One S.D. Innovations

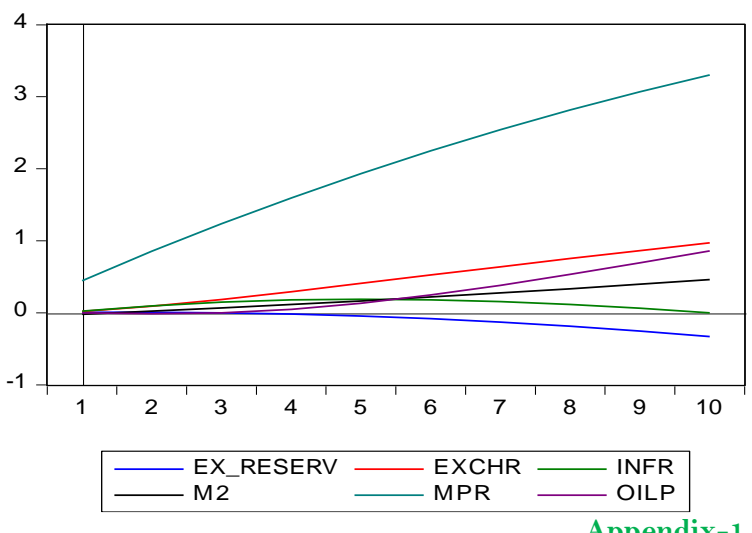

Accumulated Response of EXCHR to Cholesky One S.D. Innovations

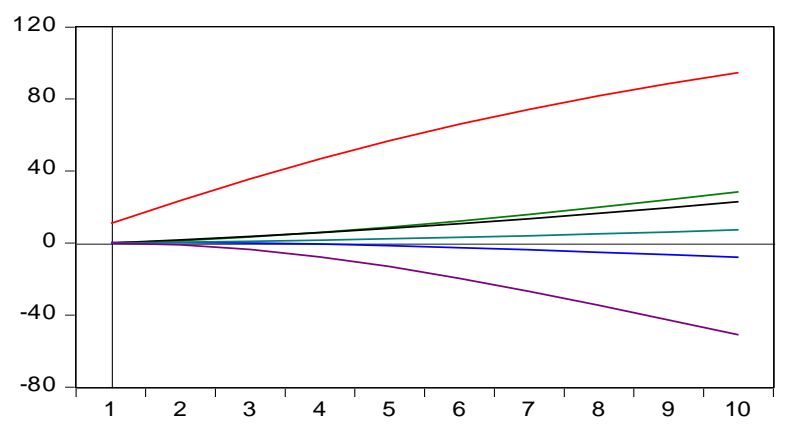

\begin{tabular}{|l}
- EX_RESERV \\
\hline M2
\end{tabular}

Accumulated Response of M2 to Cholesky One S.D. Innovations
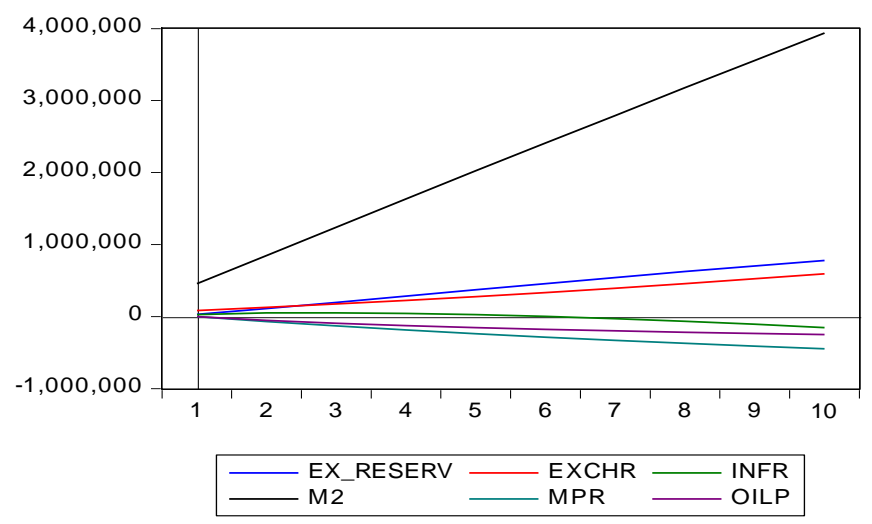

Accumulated Response of OILP to Cholesky One S.D. Innovations

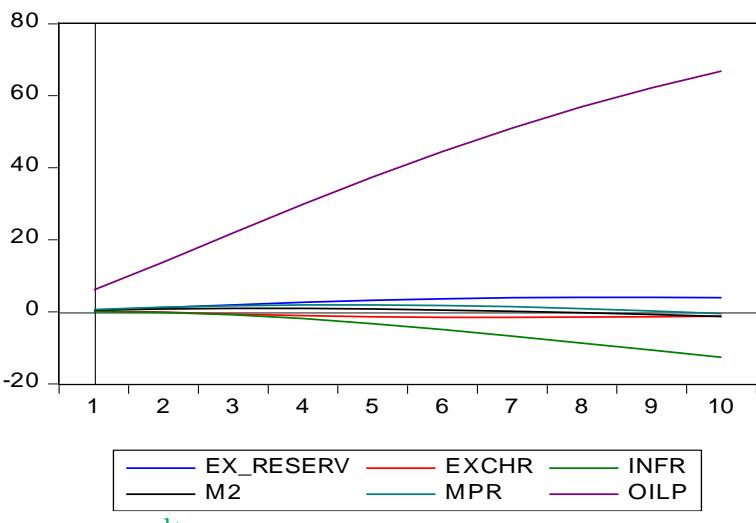

Appendix-1. Impulse response results. 